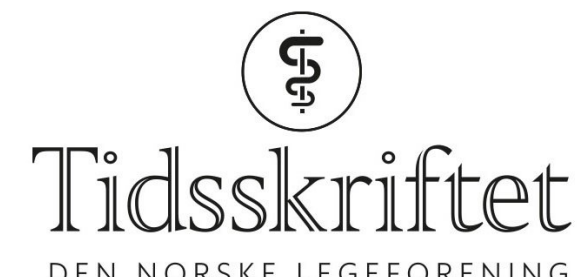

DEN NORSKE LEGEFORENING

\title{
May-Brith Lund
}

MINNEORD

GRO ØSTLI EILERTSEN

HEBE DÉSIRÉE KVERNMO

KIRSTI YTREHUS

ANTON K. GIEEVER

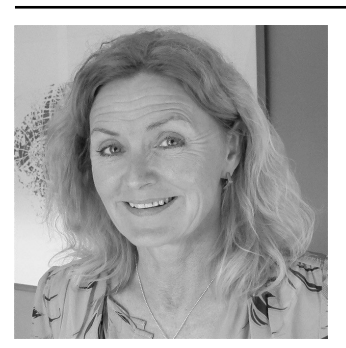

May-Brith Lund døde 29. juli 2017. Hun ble født 20. juli 196o og vokste opp i Bodø. Sammen med datteren Stine flyttet May-Brith til Troms $\emptyset$ i 1984 for å studere medisin. Der traff hun sin livsledsager Svein. Hun var innom forskning og plastikkirurgi ved Universitetet $\mathrm{i}$ Troms $\emptyset$ og Universitetssykehuset Nord-Norge, men valgte allmennmedisin. May-Brith var praksislærer for medisinstudenter, medlem i eksamenskommisjoner og engasjerte seg for en best mulig legeutdanning i Tromsø.

May-Brith hadde stor interesse for global helse. Hun var medlem i Legeforeningens utvalg for menneskerettigheter, klima og global helse i flere år. En sommer arbeidet May-Brith og Svein som leger i en landsby i Tibet og opplevde kontrasten mellom de enkle forholdene der og vår moderne medisin. I de siste årene arbeidet hun i Barentsregionen med et utdanningsprosjekt for allmennleger i Russland.

I tillegg til et stort og variert engasjement som lege, la May-Brith ned hovedtyngden av sitt arbeid som fastlege på Langnes legesenter. Hun brukte mange arbeidstimer for at senteret skulle være et av Tromsøs beste. Hun gledet seg over kunne følge familier over generasjoner, og det var mange tromsøværinger som forsøkte å få henne som fastlege uten å lykkes.

May-Brith ville ha mest mulig ut av livet, levde intenst og inspirerte andre som var rundt henne. Hun hadde en stor vennekrets og tok ofte initiativ til ulike kunst-, film-, teater- og operaopplevelser. Hun hadde alltid et «hårete mål» som skulle gjennomføres. May-Brith rakk å bestige Elbrus, Aconcagua og Kilimanjaro. Hun padlet kajakk langs Grønlands kyst. Sammen med Svein syklet hun i Albania, Slovenia, Vietnam, Nicaragua, Costa Rica, Panama og på Cuba. Hun fikk medaljer for gjennomført maraton i New York, Berlin og Stockholm. 
Langskiløpet Marcialonga gjennomførte hun også i fin stil.

Sommeren 2016 var May-Brith skipslege på Svalbard. Få uker etter hjemkomsten fikk hun den vonde beskjeden om sykdommen. Til tross for dette levde May-Brith et aktivt liv helt til siste dag.

May-Brith var en omsorgsfull lege for sine pasienter, en god kollega, en god veileder for studenter og et godt forbilde for yngre kolleger. Hun var inkluderende, en god lytter, diplomatisk og vektla alltid de beste sidene hos folk. May-Brith hadde en spesiell, varm utstråling. Hun var lett å bli glad i, og det var godt å være sammen med henne - både før og etter hun ble syk.

Vi er takknemlige for tiden vi fikk sammen med May-Brith. Våre tanker går spesielt til hennes nære og kjære familie - Svein, Stine, Anette og Bjørn.

Publisert: 28. november 2017. Tidsskr Nor Legeforen. DOI: 10.4045/tidsskr.17.0884

(C) Tidsskrift for Den norske legeforening 2020. Lastet ned fra tidsskriftet.no 